\title{
Erratum zu: Deutschlands Süden - vom Erdmittelalter zur Gegenwart
}

\section{Erratum zu:}

J. Eberle, B. Eitel, W. D. Blümel, P. Wittmann, Deutschlands Süden - vom Erdmittelalter zur Gegenwart, https://doi.org/10.1007/978-3-662-54381-8

Folgende Änderungen wurden ausgeführt:

Seite 14: Das Blockbild ragte zu weit in den Buchfalz.

Seite 33: Die 1. Spalte in Tab. 4.2 war verschoben

Seite 44: falsches Blockbild. Anstelle des Mittelmiozäns wurde das Pliozän gezeigt.

Die aktualisierten Versionen der Kapitel können hier abgerufen werden:

https://doi.org/10.1007/978-3-662-54381-8_3

https://doi.org/10.1007/978-3-662-54381-8_4

https://doi.org/10.1007/978-3-662-54381-8_5 
Tab. 4.2 Vereinfachte Darstellung der Ablagerungen im Molassebecken. Besonders vielfältig und komplex sind die Sedimente am Nordrand des westlichen Beckens. Nicht enthalten sind die spezifischen Ablagerungen des Südrandes (Alpine Fazies)

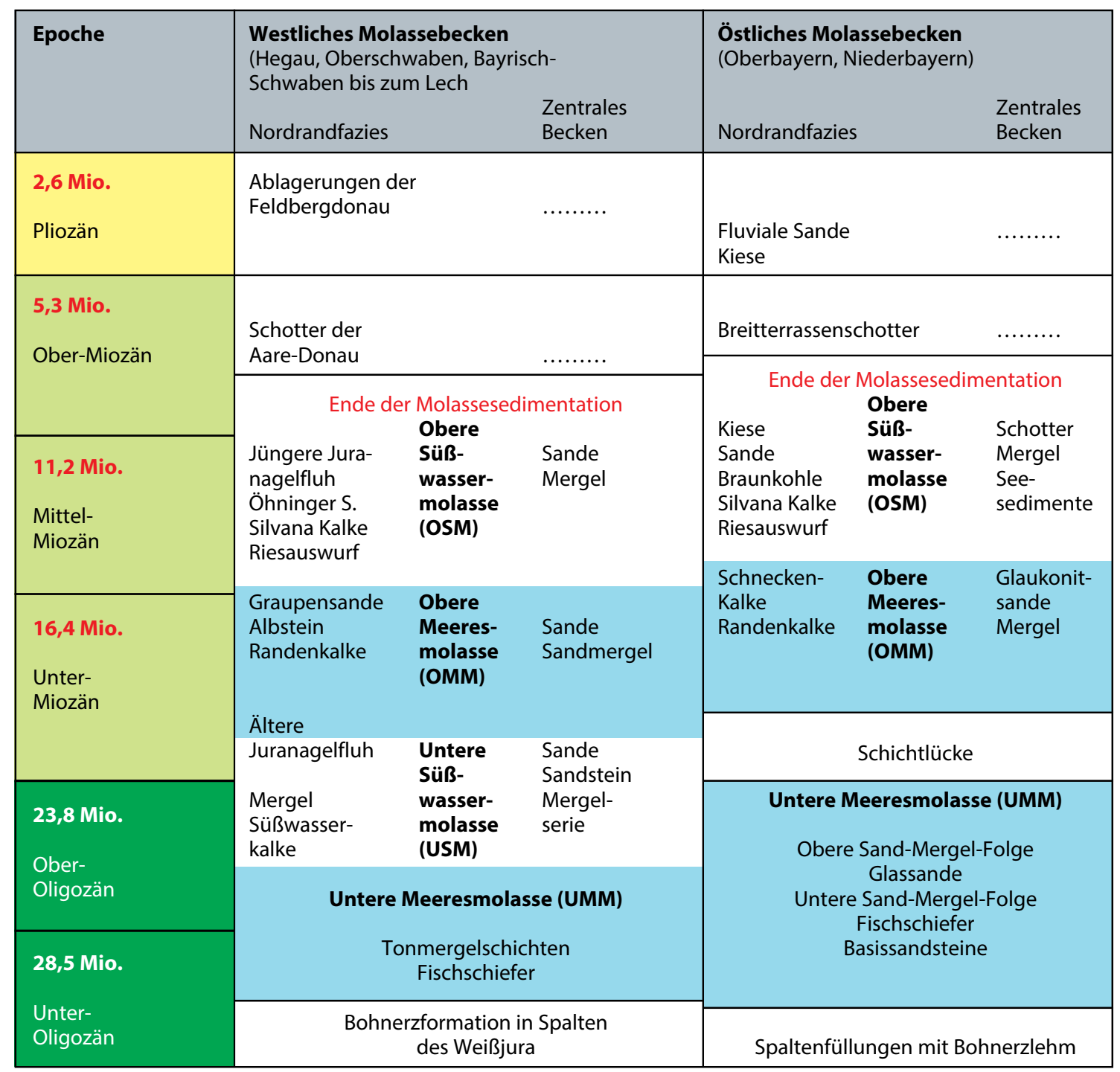

Seite 33: Die 1. Spalte in Tab. 4.2 war verschoben 
Seite 44: falsches Blockbild. Anstelle des Mittelmiozäns wurde das Pliozän gezeigt.

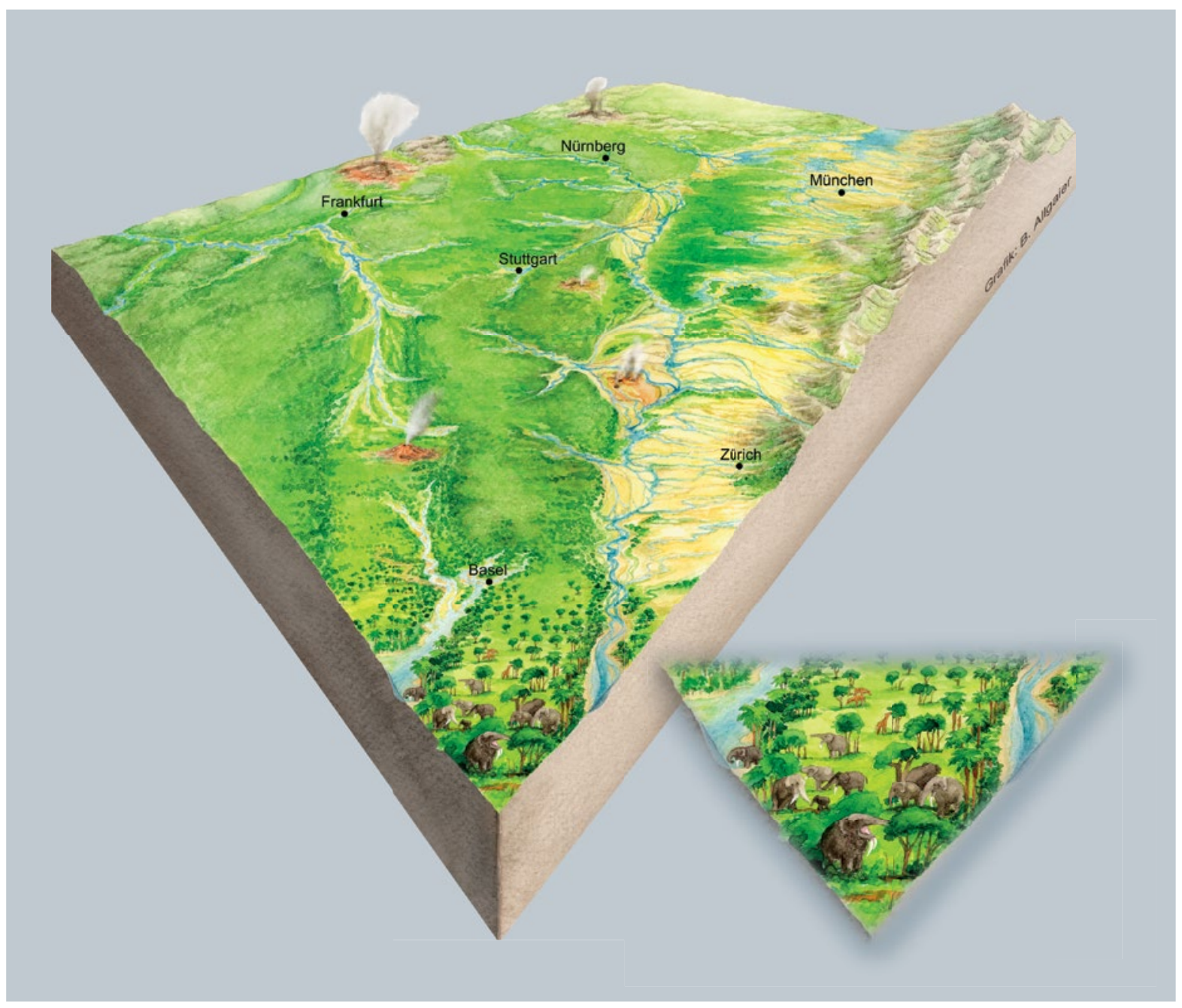

